\title{
Developing homestay to support community-based tourism
}

\section{Pengembangan homestay dalam menunjang pariwisata berbasis masyarakat}

\author{
Ilham Junaid, Nur Salam, \& Muh. Arfin M. Salim \\ Department of Tourism Management, Politeknik Pariwisata Makassar \\ Address: Jalan Gunung Rinjani, Tamalate, Makassar, South Sulawesi 90224 \\ E-mail: illank77@yahoo.co.id, achielgold@gmail.com, \& arfin70@yahoo.com
}

\begin{abstract}
Wakatobi regency has been chosen as a ten-top priority tourism destination in Indonesia. It provides the opportunity for the local community to obtain benefits through tourism. The aims of this research are 1) to study the expectation of the community related to the management of homestay as accommodation business; 2) to analyse challenges and provide recommendations concerning how to implement community-based tourism on the perspective of community as the organiser of the homestay. Qualitative research conducted in March 2018 by visiting Wakatobi for participant observation and interviews three community members or homestay managers, two tour guides and two people from the tourism industry (accommodation). The research indicates that tourism has encouraged the local community to manage homestay, although there are members of the community require motivation and support to understand the significances of managing homestay and tourism. The management of homestay by the local community links to the implementation of community-based tourism and to optimise the management of homestay; it is necessary to provide sustainable training for the local community as well as to empower people through local tourism organisation. Key attractors such as activities and alternative attractions for the visitors are essential for the management of homestay. Limited numbers of tourists who choose homestay to become the challenge for homestay management, thus, the local community expects that the increasing number of tourists as well as a willingness by tourists to choose homestay as their accommodation.
\end{abstract}

Keywords: homestay; Wakatobi; Community-Based Tourism (CBT)

\begin{abstract}
Abstrak
Kabupaten Wakatobi telah dipilih sebagai tujuan sepuluh teratas wisata prioritas di Indonesia. Hal ini memberikan kesempatan bagi masyarakat setempat untuk mendapatkan manfaat melalui pariwisata. Tujuan dari penelitian ini adalah 1) untuk mempelajari harapan masyarakat terkait dengan pengelolaan homestay sebagai bisnis akomodasi; 2) untuk menganalisis tantangan dan memberikan rekomendasi mengenai bagaimana menerapkan pariwisata berbasis masyarakat pada perspektif masyarakat sebagai penyelenggara homestay. Penelitian kualitatif telah dilakukan pada bulan Maret 2018 dengan mengunjungi Wakatobi untuk observasi partisipan dan wawancara dengan masyarakat setempat yang terdiri dari tiga pengurus homestay, dua pemandu lokal, dan dua penyedia akomodasi. Penelitian menunjukkan bahwa pariwisata telah mendorong masyarakat setempat untuk mengelola homestay, walaupun ada anggota masyarakat yang membutuhkan motivasi dan dukungan untuk memahami pentingnya mengelola homestay dan pariwisata. Manajemen homestay oleh komunitas lokal terhubung dengan implementasi pariwisata berbasis komunitas dan untuk mengoptimalkan manajemen homestay; perlu untuk memberikan pelatihan yang berkelanjutan bagi masyarakat setempat serta untuk memberdayakan masyarakat melalui organisasi pariwisata setempat. Penarik utama seperti kegiatan dan atraksi alternatif bagi para pengunjung sangat penting untuk pengelolaan homestay. Terbatasnya jumlah wisatawan yang memilih homestay menjadi tantangan bagi manajemen homestay, dengan demikian, masyarakat setempat berharap semakin banyaknya wisatawan serta kemauan wisatawan untuk memilih homestay sebagai akomodasi mereka.
\end{abstract}

Kata kunci: homestay; Wakatobi; pariwisata berbasis masyarakat (CBT)

\section{Introduction}

Wakatobi Regency, Southeast Sulawesi Province has sparked the eye of domestic and foreign tourists through their tourism activities. The designation of Wakatobi as one of the priority destinations (tentop priority destination) by the Ministry of Tourism of the Republic of Indonesia has become the 
main attraction for tourists to visit Wakatobi. Wakatobi offers marine tourism activities, research activities and cultural attractions. Hence, it widens the opportunity for the local community to engage with tourism activity to improve their economy.

Community-based tourism destinations can be implemented through the high engagement of the local community in tourism activities in Wakatobi. The local community could generate income through various sectors in tourism; one of them is the business of tourist cottage or homestay. Accommodation is the primary concern for tourists, and the availability of them is a necessity. There is a link between the accommodation business provided by the community and the implementation of communitybased tourism. The approach of community-based tourism should be implemented for a tourism destination area (López-Guzmán, Borges, and Castillo-Canalejo 2011). There is an increasing need to develop community involvement in tourism activities. Maximising public participation is the first step to realise community-based tourism. Moscardo (2008), argues that tourism is a popular alternative for most countries in the world. For developing countries, tourism has the high potential to improve people economy, not only urban communities but also rural communities.

Even though Wakatobi has been set as a significant destination, local communities need to be supported in developing tourism businesses. However, well-developed tourist destinations tend to provide more benefits only to specific groups of people who have more excellent opportunities in obtaining economic benefits (Moscardo, 2005). The ideal situation for community-based tourism development in various community groups is allowed in tourism businesses to avoid benefits centralisation to actors with high capital. Some groups have a great willingness to develop tourism area but only possess low capital to be invested in tourism activities.

Research about community-based homestay and community-based tourism is an essential measure in developing tourism destinations, especially Wakatobi. Three reasons underlie the urgency of this research - first, the need to empower the middle to lower classes to get the benefits of tourism activities. Second, community-based tourism should not be deemed merely as a concept, but as an approach with real implementation with various community groups as the main actors of tourism activities. Third, in developing the tourism sector, it takes the implementation of concrete steps in encouraging the community as the main actor. The purposes of this study are to 1) reveal the community's expectations on how to optimise the role of community as the main actor in homestay management; 2) outlining the obstacles and efforts that can be taken in optimising community involvement in supporting the application of community-based tourism.

The accommodation business in the tourism sector focuses more on hospitality where tourists or visitors will choose available accommodations. Although a hotel or other accommodation businesses employ local people, those who have not benefited from tourism should be encouraged to create and manage tourism businesses. According to Sammy (2008), people can have the opportunity to learn homestay businesses where a family's home is involved in serving tourists or visitors. By opening a homestay business, it can become an opportunity for the community to realise the importance of tourism for the community in general. This research is more focused on how the implementation and implementation of community-based tourism through the management and development of homestays in Wakatobi, Southeast Sulawesi. Sammy's research (2008) focuses on how to encourage people to manage homestays in the context of tourism.

The tourism industry consists of hotels, motels and various types of accommodation, restaurants and food and drink services, transportation services, tourist attractions, entertainment, souvenirs, etc. Tourism Act No. 10 of 2009 indicates 13 tourism businesses that can be managed by the community. The tourism businesses are tangled considering that various sector of industries related is involved in providing services to tourists before, during and after returning to their places of origin. According to Theobald (2005), tourists consumption in tourism destination varied from travel packages, accommodation, food, transportation and other forms of service. In other words, tourists' expectations during their visit involving various elements of local people. 
Homestay business has become the choice of ASEAN member in providing tourism services. In homestay businesses, visitors or tourists are allowed to explore or gain experience about the lives of rural communities (Asean 2017). With the homestay program, tourists are expected to get a different experience from tourism activities. Homestays signified by the willingness of the house owner to rent their rooms as tourist lodging places. Homestay has become an excellent alternative for foreign tourists considering their curiosity of the culture of community in their tourism destination. Compared to other accommodation businesses (e.g. hotels and inns), homestay businesses are directly managed by the local community. Hence, the local community could directly experience the benefits of tourist arrivals. However, the community needs to comprehend that homestay businesses should not damage the life order of local communities related to social, cultural and religious values.

Community-based tourism (CBT) is one concept which currently gaining popularity in various countries in the world, especially in Indonesia. The critical word attached to the term communitybased tourism, 'community', is prevalent among tourism academics and observers. The concept of CBT is widely accepted as an exciting and essential concept for a tourism destination. Community or community involvement/participation as an essential element of tourism (Cole 2006, Junaid 2017, Jurowski 2009, Saarinen 2006, Salazar 2012, Suasapha 2016). According to Timothy (2002), the local community of a destination (host community) plays an essential role in determining the shape and process of tourism development. In other words, the development of tourism in an area provides an opportunity or priority to the local community.

The concept of CBT is essential because the participation of community groups in most destinations is mainly dominated by those who have access to tourism such as government employees, tourism consultants, or individuals (Jonhson and Wilson 2000). Meanwhile, local people tend to be less involved due to their limited knowledge and skills. The situation gives the impression that communitybased tourism is only a concept that dominated by certain groups who could generate more benefit than the community itself. Therefore, community-based tourism appears to encourage local people as the main actors in the tourism business (Zapata, Hall, Lindo, \& Vanderschaeghe 2011). The low community participation in tourism sector is mainly caused by the limited knowledge about tourism in grasping the purpose of developing a tourism destination (Hall 2005, Junaid and D'Hauteserre 2017, Moscardo 2006). According to Moscardo (2008), in taking part in tourism industries, knowledge about the related sectors is highly required. To realise this, Government and benefited groups from the tourism sector need to work in real terms to help the less-knowledgeable groups to help them understand the meaning and purpose of developing a region's tourism.

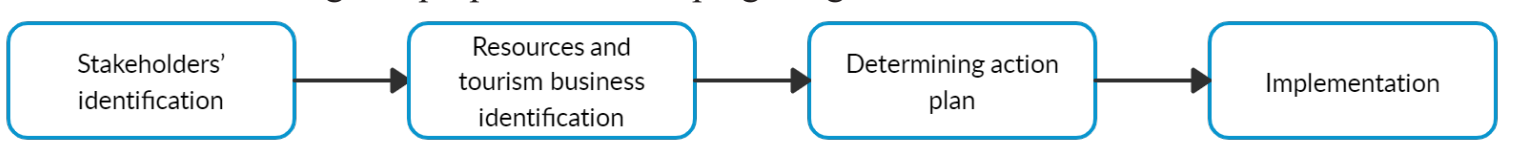

Figure 1.

The process of CBT implementation

Source: Moscardo 2008

There are several processes to empower the local community to achieve community-based tourism (Moscardo 2008). This approach addresses the issue of community involvement in the accommodation business, especially related to homestay management. The first step is identifying community groups or stakeholders in the tourism sector. Identifying stakeholders and their role is the first step to determine the next step. The second step is identifying the available resource in supporting regional tourism. This measure aims to determine the required method to raise public awareness about the importance of tourism. In the accommodation sector, identification of potential tourist attractions and opportunities for the community to open a homestay business is essential. Third, determine the strategic plan or action plan to help the community open a tourism business. The next step is the implementation phase to involve the community actively. This activity depends on the strategic plan that has been made previously based on the needs of the destination community - a description of the process, as displayed in Figure 1. 


\section{Research Method}

This study adopts the qualitative method in analysing the conditions or phenomena of tourism in Wakatobi Regency. Qualitative research is relevant in understanding factual conditions related to tourism (Phillimore \& Goodson 2004). The actual condition of Wakatobi tourism needs to be assessed to identify essential aspects in encouraging the local community and providing solutions in developing community homestay management in Wakatobi.

Data was collected through in-depth interviews and direct observation by visiting Wakatobi (WangiWangi), and the data was collected in March 2018. Researchers visit Wakatobi and meet the homestay management community to observe the development of homestay conducted by community. Indepth interviews we conducted with one of the homestay enthusiasts or managers provide essential information about the expectation of community towards homestay management. The informants involved in this research interview consisted of three community members or homestay managers, two tour guides and two people from the tourism industry (accommodation). Furthermore, the qualitative data obtained were analysed by applying the principle of data reduction, as stated by Jordan \& Gibson (2004). The process of reducing this data by carrying out the process of categorising, interpreting and presenting data for conclusions.

\section{Result and Discussion}

\section{Tourism, homestay, and Wakatobi People: Study of community expectations}

Wakatobi Tourism is becoming increasingly popular after the selection of Wakatobi by Indonesian Government as an alternative tourism destination in Indonesia. This policy has encouraged various government sectors to visit Wakatobi. Two dominant Indonesian airlines (Garuda Indonesia and Lion Air) have opened the various route to Wakatobi which encourage potential tourists to visit Wakatobi. Tourists can easily reach Wakatobi thanks to daily scheduled flights.

Given the increasing amount of tourist arrivals, the need for accommodation becomes essential, especially for destinations on islands. The Wakatobi region is divided into regions or sub-districts of Wangi-Wangi, Kaledupa, Tomia and Binongko. Visitors will arrive in Wanci, the capital of WangiWangi, the centre of Wakatobi Regency governance. Kaledupa is one of the areas which is famous for snorkelling, diving, swimming and other marine activities. Tomia and Binongko also enriched by other tourism potentials and make Wakatobi a destination for diverse tourism activities. More accommodations are available in Wangi-Wangi due to its popularity as an area for a temporary stay in Wakatobi. Therefore, Wangi-Wangi was chosen as the primary study locus. The decision to choose Wangi-Wangi as the area of study is supported by the availability of data about homestay by Wakatobi community. However, the study is not limited only in Wangi-Wangi, but also other areas in Wakatobi. Researchers identified that there are 622 homestays in Wakatobi, as illustrated in Table 1.

Table 1.

Number of homestay in Wakatobi

\begin{tabular}{lc}
\hline \multicolumn{1}{c}{ Area } & Amount of Homestay \\
\hline Kaledupa & 324 \\
Wangi-Wangi & 124 \\
Tomia & 122 \\
Binongko & 52 \\
Total & $\mathbf{6 2 2}$
\end{tabular}

Sources: Dinas Pariwasata Kabupaten Wakatobi 2016

Table 1 shows the amount of identified homestay in Wakatobi. The amount is considered sufficient to support Wakatobi tourism and adequate to fulfil the needs of Wakatobi tourists. The data shows public enthusiasm to get involved in tourism activities. Wakatobi people utilised their house for 
tourist accommodation service, indicating that tourism has been managed as a community business sector in providing accommodation. In Wangi-Wangi, where hotel and lodging businesses are easily found, the business of homestay may present challenges for managers. Researchers interviewed Wangi-Wangi people who planned to open a homestay business. He planned to build four rooms in his homestay, hoping that the business could be operated immediately. He has no worries about the possibility to find rent for the homestay. He already owned a car rental business to support transportation services in Wakatobi. He highlights the principle of excellent service to customers; thus, he believes that the homestay business he manages will be beneficial. Observing from the building, our informants' concept of the homestay is different from other homestays in Wangi-Wangi. He built the rooms separately from the house. The plan to build a homestay is based on his experience as a driver who takes guests for several years. He added that many tourists come to Wakatobi to visit other islands. Tourists stay in Wangi-Wangi mainly for a short break. Therefore, the informant believes that the homestay business he established is beneficial for tourists in taking a short break who intend to continue the trip to another island.

To provide excellent service for tourists in selling homestays service, the informant plan to provide a motorcycle for their guests. Wakatobi's geographical condition with limited modes of transportation motivates him to provide motorcycle for renters while staying at the homestay. To increase the number of homestays rent in Wangi-Wangi, several factors influence tourists to determine their homestay choice. First, homestays offer relatively lower prices compared to other accommodation businesses such as hotels. Informant planned to rent the room for 120.000 IDR per night, reasonably low prices compared to facilities received by guests. Second, maximum service with the additional services increases the attraction for tourist to stay at a homestay. The availability of Wakatobi food stalls with the concept a unique concept becomes a distinctive feature that distinguishes the homestays he manages. Hence, homestay business will remain to exist even within the availability of hotels in Wangi-Wangi.

Third, the homestay business will attract tourists when the local community can offer attraction for tourists. We conducted in-depth interviews with a community in Waha Village, who provides rooms in their homes, and resulted in different patterns of homestay management compare to the previous informant. According to the second informant, the majority of tourists who come to Wakatobi intend to enjoy marine tourism such as snorkelling and diving. Homestay is regarded as rooms in one house used by tourists to stay or to put their luggage when they visit their destination. In the area, tourists can enjoy and follow the traditional activities of the community. The homestay will be useful for tourists as a basecamp or place to stay when they are diving or snorkelling. Therefore, a homestay will be a good option for tourists if the community can combine traditional activities in Wakatobi with homestay businesses that they manage.

From the perspective of the community as parties who manage homestay, there are several expectations regarding how homestays should be managed in Wakatobi, especially in the context of community-based tourism. First, homestay is a local community business that needs to be supported and developed. The progress of Wakatobi tourism is inseparable from the availability of various accommodation businesses. Secondly, the community has realised that the Indonesian Government has supported Wakatobi as one of Indonesian most attractive tourism destination. However, there are many efforts needed to make the community aware of the importance of designation of Wakatobi as Indonesian leading tourism destination. In some regions in Wangi-Wangi, communities have formed institutions through the Tourism Awareness Group (Kelompok Sadar Wisata/Pokdarwis) and community-based tourism at the provincial level. However, these institutions tend to experienced stagnant development, while others require motivation in the management system.

This research considers that in developing tourism in Wakatobi, local community needs assistance from the local government to run the tourism business, whether in regular or sustainable activities. For example, hotels in Wangi-Wangi will have a high occupancy rate if an event conducted in the area. The moment will affect the occupancy rate of other accommodation businesses. The national and international event will not only support Wakatobi tourism but also will encourage the local 
community to establish or manage homestay businesses. An overview of homestay concepts and community expectations can be seen in Figure 2.

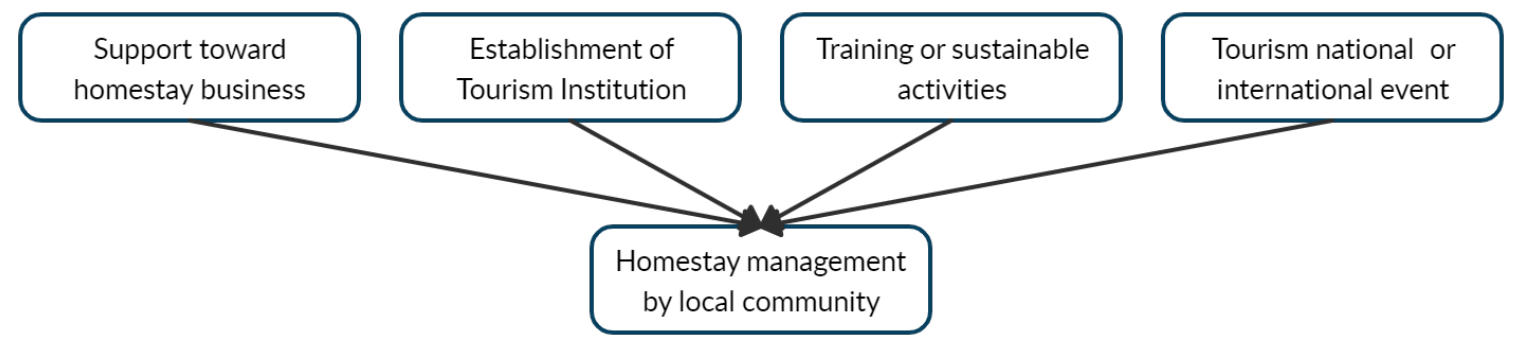

Figure 2.

Local community expectation about homestay

Sources: Researcher 2018

\section{Community-based tourism optimalisation}

In Wakatobi, there is a positive relation between homestay management by the community and the application of community-based tourism (CBT) concept. CBT is not a new concept for Wakatobi, especially those who have been actively involved in Wakatobi tourism. The formation of CBT organisations in several villages in Wangi-Wangi indicates that tourism activities with CBT are started to be regarded as the central concept. The community attempt to develop tourism by making $\mathrm{CBT}$ as a basis in tourism management activities.

Researchers conducted an in-depth study on the implementation of CBT in Wakatobi. CBT is defined as a specific group or organisation where the community is the manager or main actor in providing services. It aligns with the concept of CBT as stated by many tourism experts (Hiwasaki 2006; Jones 2005; Rocharungsat 2008). Waha is a village in Wakatobi that implements CBT concept uniquely. Homestay management remains as a community activity even though it is not directly under the context of CBT. There is an organisation that conveys the community in managing tourism in Waha Village, called Waha Tourism Community (WTC). WTC is an institution that works to supervise and organise smaller institutions or organisations called CBT. There are two central institutions named Waha Tourism Community and Tourism Awareness Group (Pokdarwis). These two institutions vary on their organisational goals. WTC is focused on conservation of Waha's natural resources as a tourist attraction. Waha has the marine potential of coastline, which make the place is famous as a diving spot.

On the other hand, Pokdarwis focused on how to manage Waha tourism by optimising people's role as the main actors. Pokdarwis manages the CBT group, one of the affiliations is CBT homestay. In other words, CBT is established by Pokdarwis and focused on community groups that manage various businesses, including accommodation (homestay).

This research supports the identification of problems and what measure can be done to support community participation in supporting community-based implementation. In line with the objectives of this study, three efforts are provided as alternatives in developing tourism under the perspectives of CBT and homestay management. First, the related institutions or organisations in tourism should be identified and supported by the government as the decision-makers. The support encompasses various aspects such as funding assistance, organisation, provision of education and training for the local community and public engagement in developing tourism in the area.

Secondly, homestay is an vital alternative to invite local people to understand and receive the benefits of tourism. Homestay managed by the community cannot be beneficial unless there are other attractions for tourists to choose the homestay in the area. If critical attractions of the area cannot be realised, tourists will prefer to stay in a hotel or another lodging during their visit to Wakatobi. For instance, the plan to build homestay given by the first informant in Wanci utilised the advantage of location and other business opportunities in the surrounding area. The additional strategy they 
propose to attract tourists to use their service is promoting the concept of Wakatobi-style food stalls and choose the location at the heart of Wanci. He also offers to provide motorcycle as additional facilities for guest.

Activities offered by homestay owners in Waha Village dan influence tourists prefer to stay in homestay than in the hotel. In Waha and the surrounding areas, the approximately $5 \mathrm{~km}$ distance from the Wanci town encourages tourists to choose a homestay instead of a hotel. However, the main challenge for homestay managers is that they are not equipped with effective marketing strategy as Hotels. Thus, homestay managers should provide a different experience for guests. Such incentives will be the hallmark of a homestay business and differentiate them with other accommodation business. Hotels that offer modern ambience to their customer can be regarded as opportunities for homestay to provide the experience for tourists to see firsthand the traditional activities of the community. Homestay is the answer for visitors who wish to engage with locals traditional activities.

Third, community-based tourism in Wakatobi can be achieved by developing alternative tourism options other than marine tourism. Observing the needs of tourists who aim to enjoy Wakatobi nature, the archipelago offers marine experience such as snorkelling and diving. The existing situation in Wakatobi is considered adequate to fulfil the tourists' expectation. However, tourist destinations need to be supported by alternative types of tourism. Researchers have identified other types of tourism, such as cultural tourism such as Liya Togo Fort and traditional culinary tourism. The local community should explore for another potential to increase Wakatobi attraction for tourists in luring them to stay longer in a Wakatobi.

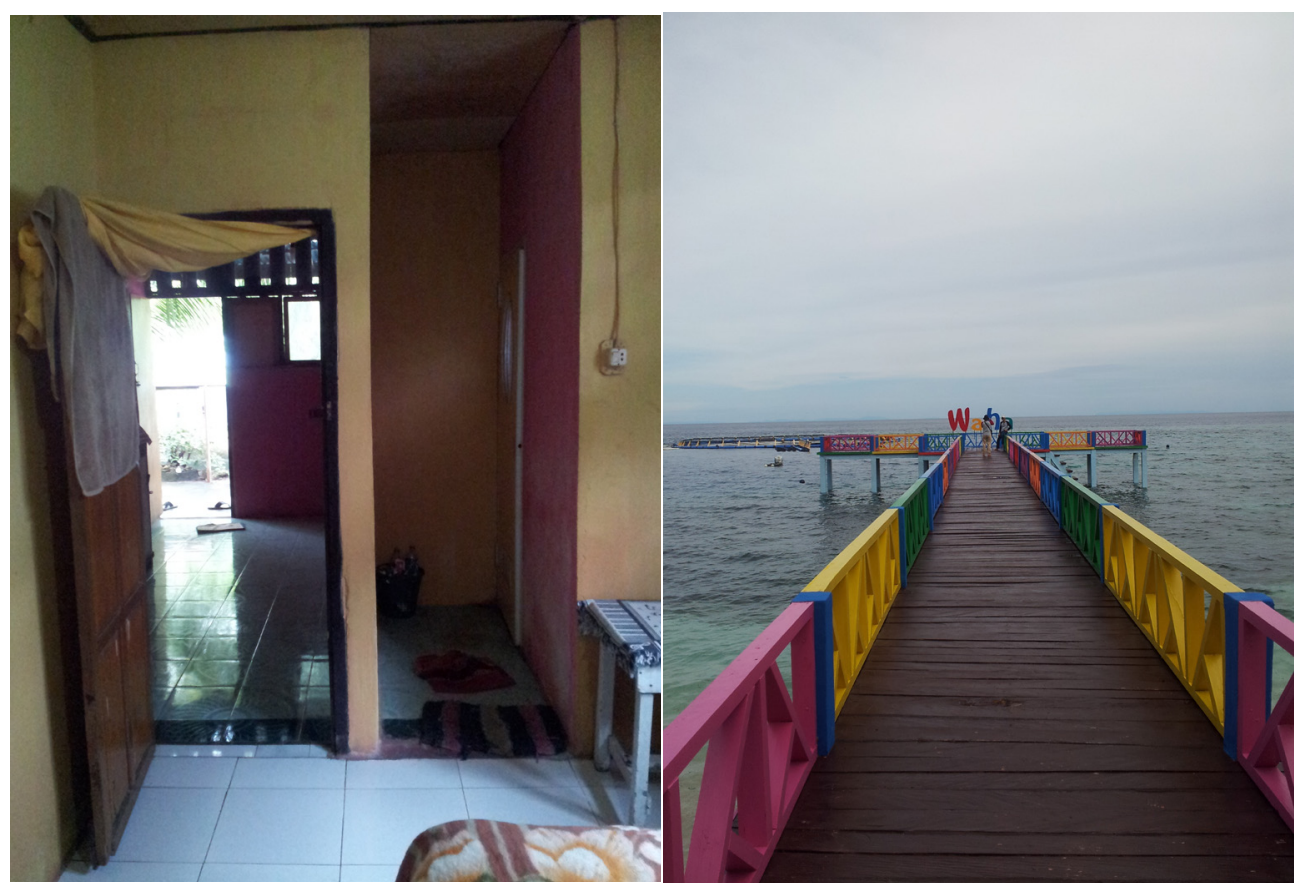

Figure 3.

Homestay and key attraction for Wakatobi Visitors

Sources: Researcher 2018

Tourism potential of a destination is not only the pride of the people. People willingness to rent rooms from their house as tourist accommodation should be followed up by the local government. The decision of the central government in choosing Wakatobi as an alternative destination aside from Bali and other cities in Indonesia is an excellent opportunity to invite people to utilised tourism sectors as an alternative for economic activities. This research recommends the importance of providing regular training or education to community groups in the form of short training or workshops.

The fourth approach employed in this research is providing implementation training for people who will engage with tourism activities. For instance, tour guide training, English skills, and hospitality 
which conducted regularly is an essential and beneficial step for the community. The homestay management community also needs to be given training on how to operate a homestay business, serve tourists with local wisdom principles and provides excellent services toward guests. Homestay and other tourism businesses in Wakatobi must apply the principle of inseparable service of related sectors covering transportation providers, tour guides, hotels or homestays. Thus, the tourist satisfaction and comfort level about a destination will not only determined by the type of service, rather than the accumulation of experience gained during their visit.

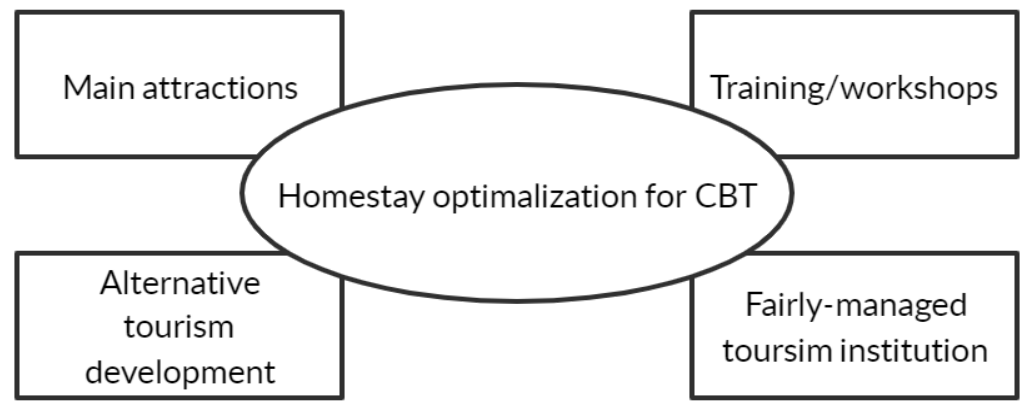

Figure 3.

Homestay optimalisation for CBT

Sources: Researcher 2018

\section{Conclusion}

Community-based tourism (CBT) has become the choice of Wakatobi community in developing tourism. It appears from the creation of tourism institutions that use the term community-based tourism (CBT). CBT is not a new concept for Wakatobi people, especially for observers and tourism practitioners. CBT allows other communities to get involved in tourism activities through managing homestays, alternative accommodation businesses for community groups who wish to engage in tourism activities.

Given the number of homestays in Wakatobi, it is apparent that community enthusiasm to manage homestay business is high. However, homestay business should provide profits to the local community. It is not only about having a homestay but also about how to attract tourist to choose homestay as a place to reside during their stay in Wakatobi. Thus, it is necessary to provide ongoing training to the community on homestay management. There is a growing urge to empower communities through tourism organisations at the village level. Homestay should have the main attraction to maintain its existence; otherwise, a homestay will only function as a seasonal place to stay, such as during an event or high-peak season. To support the management of homestays by the community and the application of community-based tourism, government's commitment and support are essential to empower local people.

\section{References}

Asean (2017) Asean Homestay Standard. Jakarta.

Cole S (2006) Cultural Tourism, Community Participation and Empowerment. In: MK Smith \& M Robinson (eds). Cultural Tourism in a Changing World: Politics, Participation and (Re) Presentation. Clevedon: Channel View, pp. 89-103.

Dinas Pariwisata Kabupaten Wakatobi (2016) Data Kelembagaan, Sumber Daya Manusia Kepariwisataan dan Ekonomi Kreatif Kabupaten Wakatobi.

Hiwasaki L (2006) Community-based tourism: A pathway to sustainability for Japan's protected areas. Society and natural resources: An International Journal 19 (8):675-692. https://www. tandfonline.com/doi/abs/10.1080/08941920600801090.

Jones S (2005) Community-based ecotourism: The significance of social capital. Annals of Tourism Research 32 (2):303-324. https://doi.org/10.1016/j.annals.2004.06.007. 
Jordan F \& Gibson H (2004) Let Your Data Do the Talking: Researching the Solo Travel Experiences of British and American Women. In: J Phillimore \& L Goodson (eds). Qualitative Research in Tourism: Ontologies, Epistemologies and Methodologies. New York: Routledge, pp. 215-235.

Junaid I (2017) Strategic efforts in developing indigenous tourism: A case study in Selayar Island Regency. Masyarakat, Kebudayaan dan Politik 30 (3):266-277. http://dx.doi.org/10.20473/ mkp.V30I32017.266-277.

Junaid I dan D'Hauteserre A-M (2017) Collaborative schemes for anticipating negative impacts of the tourists' visit. Tourism and Hospitality Management 23 (2):279-294.

Jurowski CA (2009) Building community capacity for tourism development. Annals of Tourism Research 36 (4):751-752.

López-Guzmán T, Borges O, \& Castillo-Canalejo AM (2011) Community-based tourism in Cape Verde - A case study. Tourism and Hospitality Management 17 (1):35-44.

Moscardo G(2008) Community Capacity Building: An Emerging Challenge for Tourism Development. In: G Moscardo (ed). Building Community Capacity for Tourism Development. Wallingford: CABI, pp. 1-15.

Moscardo G (2005) Successful Tourism Development for Regions. Ninth National SEGRA Conference Proceedings. Management Solutions, Brisbane, Australia.

Moscardo G (2006) Contested Visions of Tourism: Social Representations of Tourism Development". Paper presented at the ATLAS Africa 2006 Conference, Mombasa, Kenya.

Phillimore J \& Goodson L (2004) Progress in Qualitative Research in Tourism: Epistemology, Ontology and Methodology". In: Jenny Phillimore \& Lisa Goodson (eds.), Qualitative Research in Tourism: Ontologies, Epistemologies and Methodologies, pp. 3-29. New York: Routledge.

Rocharungsat P (2008) Community-Based Tourism in Asia. In: G Moscardo (ed). Building Community Capacity for Tourism Development. Wallingford: CABI. 60-74.

Saarinen J (2006) Traditions of sustainability in tourism studies. Annals of Tourism Research, 33, 1121-1140. https://doi.org/10.1016/j.annals.2006.06.007.

Salazar N (2012) Community-based cultural tourism: Issues, threats and opportunities. Journal of Sustainable Tourism 20 (1):9-22.

Sammy J (2008) Examples of Effective Techniques for Enhancing Community Understanding of Tourism. In: G Moscardo (ed). Building Community Capacity for Tourism Development, Wallingford: CABI, pp. 75-85.

Suasapha AH (2016) Implementasi pariwisata berbasis masyarakat dalam pengelolaan Pantai Kedongan. Jurnal Master Pariwisata (Jumpa) 2 (2):58-76. https://doi.org/10.24843/ JUMPA.2016.v02.i02.p04.

Timothy DJ (2002) Tourism and community development issues. In: R Sharpley \& DJ Telfer (eds). Tourism and Development: Concepts and Issues. Clevedon: Channel View, pp. 149-164.

Theobald WF (2005) The meaning, scope, and measurement of travel and tourism. In: WF Theobald (ed). Global Tourism. Amsterdam: Elsevier, pp. 5-24.

Zapata MJ, Hall CM, Lindo P, \& Vanderschaeghe M (2011) Can community-based tourism contribute to development and poverty alleviation? Lessons from Nicaragua. Current Issues in Tourism 14 (8):725-749. 